Available online at JECE (Journal of Early Childhood Education)

Website: http://journal.uinjkt.ac.id/index.php/jece

Permalink/DOI: http://dx.doi.org/10.15408/jece.v2i2.17055

JECE, 2 (2), Desember 2020, 97-112

\title{
EFFECT OF FAMILY FACTOR AND CHILDREN'S SCHOOL READINESS IN INTEGRATED WASTE TREATMENT PLACES: PATH ANALYSIS
}

\author{
Nur Rochimah¹, Myrnawati Crie Handini², Hapidin ${ }^{3}$ \\ 1STKIP Muhammadiyah Bogor, Indonesia \\ 2,3Universitas Negeri Jakarta, Indonesia \\ Corresponding e-mail: nurrochimah@stkipm-bogor.ac.id
}

\begin{abstract}
Many factors can affect children's school readiness, one of which is the family as their closest environment. This research aimed to analyze the effect of family socioeconomic status, family stress, and parental involvement on children's school readiness. This research involves 113 parents and students of group B Kindergarten in the Integrated Waste Processing Site (TPST) in Bantargebang District, Bekasi City, West Java Province. This sample was obtained using the multistage random sampling technique. This study uses path analysis techniques. This study indicates that socioeconomic status, family stress, and parental involvement do not directly affect Children's school readiness. However, family socioeconomic status has a negative direct effect on family stress, and family stress can also have a negative direct effect on parental involvement in children's education. These findings imply that it is important to create a warm and supportive family environment to optimally carry out their roles and functions in children's education.
\end{abstract}

Keywords : socioeconomic status, family stress, parent involvement, children school readiness

\begin{abstract}
Abstrak
Banyak faktor yang dapat mempengaruhi kesiapan anak bersekolah, salah satunya adalah faktor keluarga sebagai lingkungan terdekat dengan anak. Penelitian ini bertujuan untuk menganalisis pengaruh status sosial ekonomi keluarga, stress keluarga, dan keterlibatan orang tua terhadap kesiapan anak bersekolah. Penelitian ini melibatkan 113 orang tua dan murid kelompok B Taman Kanak-Kanak di wilayah sekitar Tempat Pengolahan Sampah Terpadu (TPST) yang berada di Kecamatan Bantargebang, Kota Bekasi, Provinsi Jawa Barat. Contoh tersebut diperoleh dengan menggunakan teknik multistage random sampling. Penelitian ini menggunakan teknik analisis jalur. Hasil penelitian ini menunjukkan bahwa status sosial ekonomi, stress keluarga, dan keterlibatan orang tua tidak berpengaruh langsung terhadap kesiapan anak bersekolah, namun status sosial ekonomi keluarga berpengaruh langsung negative terhadap stress keluarga dan stress keluarga juga dapat berpengaruh langsung negatif terhadap keterlibatan orang tua dalam pendidikan anak. Implikasi dari temuan tersebut adalah bahwa penting untuk menciptakan lingkungan keluarga yang hangat dan penuh dukungan agar keluarga dapat menjalankan peran dan fungsi nya dalam pendidikan anak secara optimal.
\end{abstract}

Kata Kunci : Status sosial ekonomi, stress keluarga, keterlibatan orang tua, kesiapan anak bersekolah 


\section{Introduction}

The government's early childhood education program aims to help children be ready to enter further education levels. This important objective is stated in the 2003 National Education System Law. This shows that the Indonesian government is very aware of the importance of preparing children from this age to have readiness, physically, socially, and emotionally to enter the next education level.

Children's school readiness is an important topic that needs to be discussed and considered in education, especially early childhood education. Various research results have confirmed that children's school readiness at the Early Childhood Education (PAUD) level will affect children's success at a higher level of education. The results of (van Zyl, 2011) study confirm that children's school readiness is significantly related to children's academic performance at the next level of education. In addition to better achievement in academics, school readiness is also an asset for children to adapt well at the elementary school level (Yüksel, Küçükoğlu, \& Ünsal, 2013). This is reinforced by the results of long-term research conducted by (Pan, Trang, Love, \& Templin, 2019), concluding that children who have positive development in terms of academics, personality, and social skills at pre-school age will have better achievement at the next stage of education. The child's school readiness does not merely influence a child's success, but the school readiness is also the starting point for the child to adapt well to the new school environment to achieve their best.

The results of research conducted by the World Bank (2010) show that when compared to several other countries, children in Indonesia show lower school readiness and have not been optimally fulfilled; they still need further assistance to improve several aspects of development, which are indicators of children's school readiness. These findings are consistent with (Nurhayati, 2018) research conducted in several provinces in Indonesia, showing that most early childhood children in Indonesia are cognitively ready but do not yet have optimal readiness in other aspects such as language, motor skills, and social emotions.

This condition is supported by data that shows that there are still students who repeat classes at the elementary school level. Based on reports of facts and figures on education in West Java Province, it shows that the rate of repeating classes for the 2012-2013 school year for the primary school level in districts and cities is entirely below 0.8 percent. Bekasi City, the research location, ranks the third city with the highest repeat rate for elementary school level than eight other cities in West Java Province, namely 1,494 children or 0.589 percent (Disdik Jabar, 2014).

In addition to individual children's factors, children's school readiness is also influenced by family environmental factors, including family socioeconomic background, parent-child relationship, children's learning environment at home, and 
family functioning, which is described by the level of stress felt by the family (Crosnoe \& Cooper, 2010). One of the important functions that the family has is the function of education. Currently, not all families are in a favorable condition that allows the family to carry out its functions optimally. This condition is indicated by the relatively large number of pre-prosperous families, which illustrates the family's low socioeconomic status. Based on BPS data (2014), 11.25 percent of Indonesia's population is still classified as poor. In the Bekasi City area, it is reported that there are 23,756 heads of families classified as pre-prosperous families; this number is the largest compared to eight other cities in West Java Province (BPS Jabar, 2014 ) and based on data from BPS Kota Bekasi (2014). One of Bekasi City districts with quite several pre-prosperous families is Bantargebang District, with 1,127 households.

BPS Kota Bekasi also noted that Bantargebang District has an Integrated Waste Processing Site (TPST), which accommodates 6,000 tons of waste from DKI Jakarta Province every day. These conditions make the environment around the Bantargebang TPST not very conducive for children to grow and develop optimally. Based on the observations, the noisy environment in the living and school environment due to the large number of large garbage trucks passing by causes children to scream when they speak and act more aggressively. (Xie \& Gan, 2017) argue that the socioeconomic status of the family is one of the main factors affecting children's school readiness; children who come from low socioeconomic backgrounds are more at risk of having socio-emotional problems because it is related to the family's ability to provide an environment learning that is conducive to children. Also, the polluted area's condition causes children to be exposed to various diseases, especially diseases related to the respiratory tract, digestion, and skin, so that some children are absent from school every day due to illness. Diseases suffered by children will certainly hinder the development of children, which affects children's school readiness.

Apart from the family's socioeconomic status, another risk factor that can also affect children's school readiness is the family's stress. Parents' stress can affect the stability of the family's functioning in carrying out the function of taking care and education (Masarik \& Conger, 2017). Parents who experience stress have the potential to engage in parenting practices that are unresponsive, less stimulating, and can lead to neglect and acts of violence. Low quality of care will harm children's development, and in the end, children who are in an unfavorable and stressful family environment are at low risk of school readiness.

Apart from socioeconomic status and family stress, other things are also thought to affect children's school readiness, namely parental involvement. Parental involvement is one of the things that can support children's learning and development. (Majzub \& Rashid, 2012) state that children whose parents are 
involved in children's education will have better school readiness than children with less involved parents. Likewise, (Bhise CD \& Sonawat R, 2016) state that parents' involvement in children's education is a very important supporting aspect so that children are physically, socially, emotionally, and academically ready. However, in reality, parents often ignore their involvement in stimulating children at home and rely more on teachers as the main educators for their children. This illustrates that parental involvement is an important component in an education system that can complement each other and be designed to support children's development and success in school.

Based on this explanation, through this research, the researcher tries to obtain an overview and analyze that the children's school readiness is not only about the individual child itself but family factors (socioeconomic status, family stress, parental involvement) as a micro-system for children that has a supportive influence to the children's school readiness. This is especially for children who live in areas with unfavorable conditions for children, namely in the Bantargebang Integrated Waste Processing Site (TPST) area.

\section{Children's school readiness}

Children's school readiness has a broad definition, including (Pekdogan \& Akgul, 2016), which states that children who have good school readiness are children who can adapt to school, are physically mature, motivated to go to school, and have a variety of general knowledge and have qualified development skills. In all aspects of development, and can use them at a higher educational stage. (Bhise CD \& Sonawat R, 2016) also define children's school readiness as a multi-faceted concept that refers to the child's achievement of a certain set of competencies that help children succeed when entering school. Thus children's school readiness can be interpreted as a set of skills and knowledge that children need to adapt effectively and efficiently according to the school environment's demands. The knowledge and skills include motoric, language, cognitive, social, emotional, and children's learning involvement.

The children's school readiness has several indicators, including (Setiawati, Izzaty, \& Triyanto, 2017) which mentions several abilities which are indicators of children's school readiness, namely abilities in cognitive and language aspects; social emotions; other aspects (concentration skills, age, and attention of parents); fine motor skills; art; and moral and religious aspects. Likewise, (P. G. Williams \& Lerner, 2013) state that children who are ready to go to school have several indicators, namely physically healthy and good motor development; have good emotional, social readiness; have a good approach to learning (enthusiasm, curiosity, temperament, values, and culture); good language development; and general and 
cognitive knowledge (initial literacy). This indicator shows the aspects of the child's internal readiness.

In addition to internal factors, many factors can affect children's school readiness originating from external factors, one of which is according to the opinion of (Shaari \& Ahmad, 2016) which states that the physical environment has a direct influence on children's school readiness, meaning that to support children's school readiness requires an environment. Conducive learning and have sufficient learning facilities. (Isaacs, 2012) states that poverty is one factor that strongly influences children's school readiness; five-year-old children from low-income families have lower school readiness than children from families with the middle and upper socioeconomic status. This shows that environmental conditions, especially families, have a significant role in shaping children's school readiness.

\section{Socioeconomic Status}

As previously stated, one of the factors that influence children's school readiness is the socioeconomic status of the family. Socioeconomic status is often measured as a combination of family income, type of work, and parents' educational status (Santiago, Wadsworth, \& Stump, 2011). (Gururaj \& Maheshwaran, 2014) also state that socioeconomic status is the position of an individual or family in the hierarchical social structure of society, which consists of a combination of social and economic variables measured based on three indicators, namely family income, type of work of the head of the family, and the family head's educational status. This is per the opinion of (Rathod \& Ningshen, 2012), who also define socioeconomic status as a combination of overall economic and sociological measures and/or the relative economic and social position of a family based on income, education, and employment.

(Duvall, 1971) stated that the socioeconomic status as the family's position in society's social structure could be determined by various factors, namely the type of occupation, source of income, type of house to live in, and the conditions of the neighborhood. However, some determine the socioeconomic status of a family based on other indicators such as health status, access to health insurance, food security, housing ownership conditions and status, education level, and access of family members to the labor market (Jenkins, Hooper, Woolley, \& Bellis, 2013). Based on this concept, the family's socioeconomic status in this study can be conceptualized as a measure that describes the family's social conditions and resources.. It is described by indicators, namely the length of education taken by parents, total family income, asset ownership, housing conditions, access to health facilities, health insurance ownership, clean water sources, and active family members in community organizations. 


\section{Family Stress}

(Wilmoth, 2009) define family stress as a condition where environmental demands exceed the individual or collective family resources, disrupting the family system. Also, (Sunarti, 2012) uses the term pressure to describe the stress felt by the family and defines it as the family's perception of the problems it feels, which based on its source, can be divided into three components, namely: economic pressure, psychological pressure, and social pressure.

(Leinonen, Solantaus, \& Punamäki, 2002) show that the family's economic difficulties can cause family economic stress. Three components can be used to measure the economic difficulties, namely the level of income, changes in income, and job stability. (Aneshensel, 1992) states that stress is a condition in which individuals feel uncomfortable or disturbed. Conditions in which individuals feel uncomfortable and feel disturbed due to their relationship with the social environment are social stress.

(Lazarus, 1993) states that stress is an individual's perception of the burden or stressor that an individual receives. Psychological stress occurs due to a relationship with the environment and how the individual can sense the burden or stressor he receives, whether the individual will consider that burden to be a threat, danger, challenge or even benefit for himself. Thus, based on these concepts, family stress in this study is defined as a family perspective on threatening or unpleasant conditions, both from outside and within the family. The source can be classified into three types: economic stress, social stress, and psychological stress.

\section{Parental Involvement}

Family is the first environment for children to learn before entering school. Therefore, parents have a very important role in supporting early childhood education and children's school readiness. (Zeynep, 2016) states that there are three dimensions of parental involvement, namely: (1) parents' attitudes, values, and practices in raising children in the parenting process; (2) formal and informal relationships between parents and the school environment of their children; and (3) responsibility for learning achievement which refers to the emphasis in educational activities that promote school success. (Hornby, 2011) also mentioned the same thing, which explains that parental involvement is the participation of parents or anyone involved in carrying out childcare roles in their children's educational process and experiences, including involvement in the learning process at home also involvement in activities at school.

Parental involvement in this study can be defined as parents or families' participation in the children's education process, which includes caring for, building relationships between families and schools, and being involved in children's learning process at home. Many factors can affect parental involvement, some of which come 
from ecological factors that affect children, namely the family's socioeconomic characteristics, economic pressures, and neighborhood context. These three factors can predict parental involvement in early childhood education (Waanders, Mendez, \& Downer, 2007).

\section{Methods}

This study uses a causal associative quantitative approach with path analysis techniques or models. The research was conducted in group B Kindergarten in TPST Bantargebang, Bekasi City, in 2015. A total of 113 children and their parents were involved in this study; samples were taken from PAUD institutions close to Bantargebang TPST. The technique of collecting data on socioeconomic status (X1), family stress (X2), and parental involvement (X3) was carried out through a selfreported questionnaire by the sample parents. In contrast, data on children's school readiness $(\mathrm{Y})$ was obtained through direct assessment by Researchers using a questionnaire guide that includes aspects of children's school readiness.

Before the questionnaire was used, the four variables were tested with the results. Namely, there were 12 valid statements of socioeconomic status from 16 items tested with a reliability value of 0.735 and 38 statements of valid family stress instruments from 40 items tested with value reliability of 0.957 . The instrument trial results also showed that out of 34 items of parental involvement instruments tested, there were 26 valid items with a reliability value of 0.926 , and of the 41 items of the children's school readiness instruments, there were 27 valid items with a reliability value of 0.826 . The data obtained were analyzed using descriptive statistics and inferential statistics with path analysis techniques. Testing requirements analysis was done by using the estimated error test using the Liliefors test and linearity test.

\section{Results and Discussion}

The children's school readiness is the main key for children to adapt to the transition they are going through. The transition is not only from home to school or from kindergarten to primary school but also includes a transition from a narrower to a much wider range of interactions, a transition from more personal mentoring learning to more independent learning, a transition from the same age environment towards the school environment with students of various ages. Children's success in preparing for this transition is an important basis that can affect their future achievement. This study developed a model that describes the factors that can affect children's school readiness, either directly or indirectly. This study's structural model consists of three substructures, namely substructure 1 consisting of variables $\mathrm{X} 1, \mathrm{X} 3$, and $Y$; substructure 2 consists of variables $\mathrm{X} 1, \mathrm{X} 2$, and $\mathrm{X} 3$; substructure 3 consisting of variables $\mathrm{X} 1$ and $\mathrm{X} 2$ (Figure 1). 


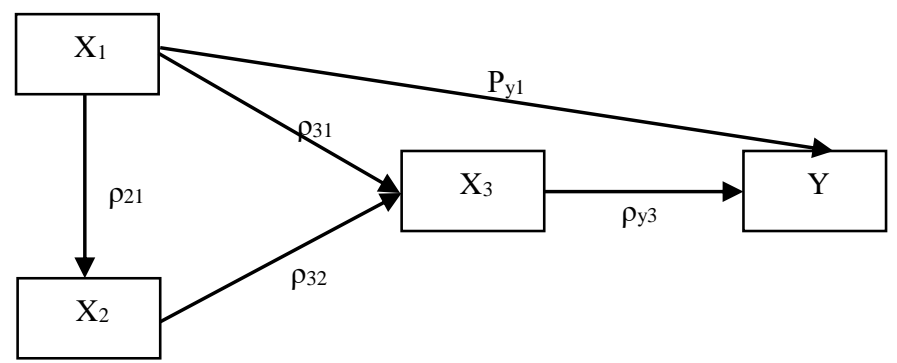

Figure 1. The constellation of the structural model

\section{a. Substructure 1 path coefficient calculation}

The causal relationship between variables in substructure 1 consists of endogenous variables, namely variable $Y$, and two exogenous variables, namely $\mathrm{X} 1$ and $X 3$. The path coefficient for substructure 1 is expressed in the equation $Y=\rho 1 X 1$ $+\rho 3 X 3$. The causal relationship in substructure 1 is visualized in Figure 2.

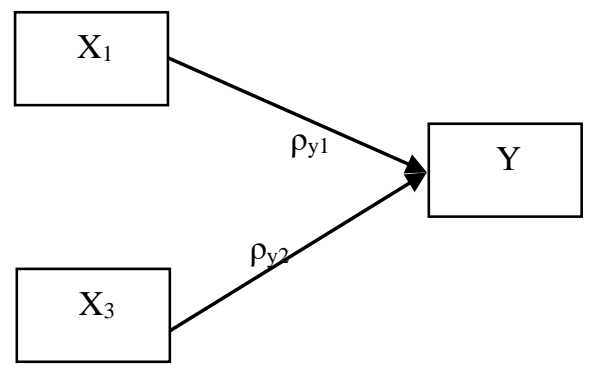

Figure 2. Substructure model 1

The results of the calculation show that the path coefficient of $\mathrm{X} 1$ to $\mathrm{Y}$ is -0.002 and $\mathrm{X} 3$ to $\mathrm{Y}$ is 0.031 with the coefficient of reflection (Rsquare $=\mathrm{R} 2 \mathrm{y} 13)=0.001$. The coefficient of reflection shows a very small contribution. The significance value of each path is $0.985>0.05$ with tcount $(0.017)<$ ttable $(\alpha=0.05 ; \mathrm{n}=113)(1.980)$ and $0.751>0.05$ with tcount $(0.319)<$ ttable $(a=0.05 ; n=113)(1,980)$. Thus, neither socioeconomic status nor parental involvement has a direct influence on children's school readiness.

The family's socioeconomic status does not significantly affect children's school readiness because of the many empowerment programs in the region. The Bantargebang Integrated Waste Processing Site (TPST) is an area that has received much attention from various non-governmental organizations (NGOs) both at home and abroad. Many empowerment programs from NGOs and the government make children and families the target of their programs, including early childhood education services, free for children living in the area. Measurement of nutritional and health status that is routinely carried out at schools in collaboration with posyandu (informal community based child health center), providing additional 
food for children of early childhood education students, providing vegetable plant seeds planted and harvested by the parents of students to then be processed and given to PAUD children.

These programs aim to improve children's welfare to reduce the gap in developmental achievement between children who come from families with low and high socioeconomic status. This is by (Laurin et al., 2015) research results, which shows that child service programs of any kind can reduce social disparities in academics, especially for children who come from families with low socioeconomic status. Likewise, (Magnuson \& Waldfogel, 2005) stated that improving PAUD services' quality can reduce the gap in children's school readiness among children who come from different socioeconomic backgrounds. The family's low socioeconomic status is one of the risk factors for children's school readiness; through this empowerment program, the impact or influence of these risk factors can be suppressed so that it does not show a significant effect children's school readiness.

The finding that parental involvement does not directly affect children's school readiness is strengthened by (Desforges \& Abouchaar, 2003) opinion, who state that several research results show that parental involvement does not affect children's developmental achievement. This is related to the effect of parental involvement in education on children's achievement. Namely, parental involvement begins with the values adopted and parents' opinions about education, which are consistently described or shown by parents' enthusiasm and positive parenting styles. The children's enthusiasm and positive parenting affect the child's perceptions, and what is better can be internalized in the child. This impacts children's perceptions of themselves as students and affects their motivation, self-esteem, and opinions about education.

The flow of parental involvement provides direction on how children perceive education and schoolwork and increase children's motivation to succeed in education. For early childhood, motivation, and the mechanism for instilling these values need to be complemented by concrete examples of mastery of skills; for example, parents must be diligent in reading books to show how interesting and important reading books are. Parental behavior, a tangible form of parental involvement, changes, or differs according to the child's age. For early childhood, direct assistance provided by parents during the learning process is more suitable and important.

The absence of influence of parental involvement in children's education on children's school readiness in this study is thought to occur because the form of parental involvement in children's education needs to be measured and analyzed more specifically, namely not only looking at quantity but also quality, such as the quality of parent-child interaction. The quality of learning carried out at home, and 
the quality of the relationships or interactions parents have with teachers at school. Most of the research results conclude that children's school readiness is influenced by parenting practices that parents do at home, such as parenting styles for children and parent-child interactions. This is supported by (Hartas, 2011) research, which states that the quality of parent-child interaction and the closeness between the learning climate at home and school play a major role in making learning at home effective.

\section{b. Substructure 2 path coefficient calculation}

Substructure 2 consists of endogenous variables, namely the $\mathrm{X} 3$ variable, and two exogenous variables, namely $X 1$ and $X 2$. The path coefficient for the substructure 2 is expressed in the equation $\mathrm{X} 3=\rho 1 \mathrm{X} 1+\rho 2 \mathrm{X} 2$. The causal relationship in substructure 2 is visualized in Figure 3.

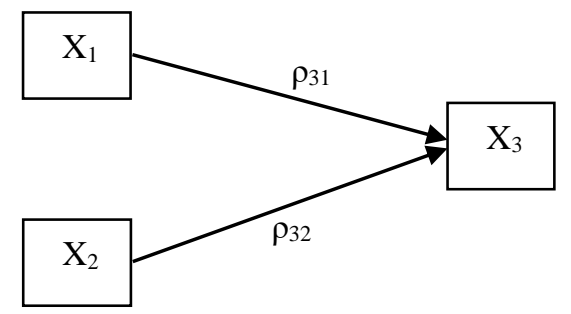

Figure 3. Substructure model 2

The calculation results show that the path coefficient value of $\mathrm{X} 1$ to $\mathrm{X} 3$ is 0.103 , with a significance value of 0.289 . This value is greater than the probability value of 0.05 and is also seen based on the tcount (1.065), which is smaller than the t-table value $(\alpha=0.05 ; n=113)(1,980)$ so that the path analysis coefficient is not significant, meaning that the socioeconomic status of the family does not have a significant direct effect on parental involvement. A different thing is obtained from the results of the path analysis of $\mathrm{X} 2$ to $\mathrm{X} 3$. The results show that the path coefficient value is -0.236 $(0.016<0.05$ with tcount $(2.438)>t$ table $(\alpha=0.05 ; n=113)(1.980)$. This means that there is a direct influence between family stress and parental involvement.

The finding that the family's socioeconomic status did not significantly affect parental involvement in this study could occur because of the many programs in schools that encourage parents to continue learning and be actively involved in children's education. Parents are present and participating in preparing additional meals for children, parents' presence in the posyandu (informal community-based child health center), program held at school, and parents' participation in preparing activities held at school. Also, a regular parent association program can gradually change parents' mindset about children's education, narrowing the gap in parents' involvement with high and low socioeconomic status. Through this program, the impact of the family's low socioeconomic status can be minimized through education 
provided to parents. Families with low education and economic disadvantages can continue to properly carry out their educational and caring functions when they have sufficient knowledge about these matters.

The finding that family stress has a significant negative effect on parental involvement is supported by the opinion of (Zang, 2012), which states that parents who experience depression have a higher probability of not paying attention or even leaving their children. (Kohl, Lengua, \& McMahon, 2000) also stated that parents, especially mothers who are stressed, can have low involvement in children's education because they lack motivation and limited energy to consistently carry out routines and be involved in their children's education. Their energy is more used to deal with the stress they feel, so that it is difficult to carry out their roles and functions as parents optimally. Depressed parents also have negative views about their lives, impacting their views on teachers, schools, and their children.

This opinion shows that parents' stress can reduce the involvement of parents in their child's education. Stress conditions that parents feel reduce their motivation to communicate with teachers regularly regarding their child's development. As a result of the economic stress he feels, parents work hard and spend more time working to have limited time to play with children, limited energy to stimulate children such as training motor, cognitive, and other aspects. Impaired mental health can also reduce parental care and warmth towards children and increase parents' likelihood of engaging in violent parenting practices, both physical and verbal.

\section{c. Substructure 3 path coefficient calculation}

Substructure model 3 consists of endogenous variables, namely family stress variables (X2) and exogenous variables, namely family socioeconomic status (X1). The substructure 3 path coefficient is expressed in the equation $X 2=\rho 1 X 1$. The results of the calculation of the path coefficient analysis $\mathrm{X} 1$ to $\mathrm{X} 2$ obtained the path coefficient value of $-0.332(0.000<0.05)$ with tcount $(3.704)>t$ table $(\alpha=0.05 ; n=113)$ (1.980). This value indicates that the family's socioeconomic status has a significant negative effect on family stress, and the causal relationship in substructure 3 is visualized in Figure 4.

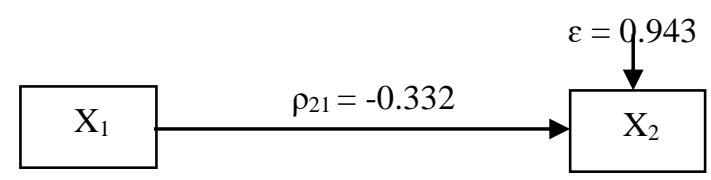

Figure 4. Substructure Model 3

These findings are consistent with the research results by (Hudson, 2005), which shows that family socioeconomic status as measured by education, income, 
and type of family work can negatively affect economic stress, affecting a person's mental health. Based on the source, stress that is felt by the family does not only come from economic factors but can also come from their social environment, such as stress due to problems with spouses, neighbors, or with extended families. The research results by (D. T. Williams, Cheadle, \& Goosby, 2015) also show that family economic problems can cause conflict with partners. This happens because, during economic hardship, wives tend to feel that they do not get a friend figure from their partner so that conflicts often occur, and the mother becomes less committed to her relationship. This stress occurs due to dyadic conflict with a partner and can also affect the relationship or interaction between mother and child.

Besides, parental education also affects stress or mental health; the results showed that individuals with low education are more likely to experience depression. This shows that individuals with higher education have broader knowledge or insights that can change perspectives or points of view in understanding the problems and economic inequalities they face to affect their psychology (Miech \& Shanahan, 2000). Thus, highly educated parents are assumed to have more knowledge to view and understand the problems faced more positively. Positive thoughts that parents have will certainly influence parents' behavior in interacting with children, which will also affect the child's quality.

This study's findings indicate that most parents, both fathers, and mothers are only elementary school graduates. Low education makes them have low confidence in seeing every problem they face, causing psychological stress, such as uneasiness, anxiety, fear, uncertainty, and sadness. These things are reflected in the indicators of psychological stress in this study. Namely, parents feel anxious about the child's future, feel anxious about the continuity of their child's education, feel afraid of losing their job, divorce, feel the uncertainty of income, etc.

The findings in this study illustrate that environmental factors around children, especially family and their relationship with the school, are also important factors to be analyzed with the achievement of children's development, reflected in the children's school readiness. This linkage illustrates that education is a system, which means that the educational effort is a complex process, includes various interconnected components, and produces educational objectives expected to identify, study, and develop various components and relationships between them.

\section{Conclusion}

This study resulted in several findings: the family's socioeconomic status and the stress experienced by the family, and parents' involvement did not significantly affect the school readiness for group B of Kindergarten children. However, the family's socioeconomic status negatively affected the stress experienced by the 
family. And then stress experienced by the family can also directly affect parental involvement in children's education. Thus, the three variables, namely socioeconomic status, family stress, and parental involvement in children's education, have a strong relationship but do not significantly affect children's school readiness.

\section{References}

Aneshensel, C. S. (1992). Social Stress: Theory and Research. Annual Review of Sociology, 18, 15-38.

Badan Pusat Statistik [BPS] Kota Bekasi. (2014). Kecamatan Bantargebang dalam angka 2014, Oktober 2014, h.35, http://bekasikota.bps.go.id/?hal=publikasi_detil\&id=217 (diakses pada 3 Desember 2014)

Badan Pusat Statistik [BPS]. (2014). Laporan Bulanan Data Sosial Ekonomi, Katalog BPS Edisi 54, November 2014, Jakarta: Badan Pusat Statistik, www.bps.go.id

Badan Pusat Statistik [BPS]. (2014). Provinsi Jawa Barat, Jawa Barat dalam Angka 2014, Bandung: BPS Provinsi Jawa Barat, h. 144, http://jabar.bps.go.id/publikasi/jawa-barat-dalam-angka-2014

Bank Dunia. Potret Perkembangan Anak Usia Dini di Indonesia. December 2010. Unit Pendidikan Kantor Bank Dunia Jakarta, 2010.

Bhise CD, \& Sonawat R. (2016). Factors Influencing School Readiness of Children. Research Journal of Recent Sciences, 5(5), 53-58. Retrieved from www.isca.me

Crosnoe, R., \& Cooper, C. E. (2010). Economically disadvantaged children's transitions into elementary school: Linking family processes, school contexts, and educational policy. American Educational Research Journal, 47(2), 258-291. http://doi.org/10.3102/0002831209351564

Desforges, C., \& Abouchaar, A. (2003). The Impact of Parental Involvement, Parental Support and Family Education on Pupil Achievements and Adjustment: A Literature Review with. Education, 30(8), 1-110. http://doi.org/10.1016/j.ctrv.2004.06.001

Dinas pendidikan Provinsi Jawa Barat. Fakta dan Angka Pendidikan di Jawa Barat. (2014). h. 82. http:/ /www.disdik.jabarprov.go.id/download/Statistik/[4]\%20Fakta\%20dan \%20Angka\%20Booklet.pdf (diakses pada 11 November 2014)

Duvall, E. M. (1971). Family Development Fourth Edition. USA: J.B Lippincott Company.

Gururaj, \& Maheshwaran. (2014). Kuppuswamy ' s Socio-Economic Status Scale - A 
Revision of Income Parameter For 2014. International Journal of Recent Trends in Science and Technology, 11(1), 1-2.

Hartas, D. (2011). Families' social backgrounds matter: Socio-economic factors, home learning and young children's language, literacy and social outcomes. British Educational Research Journal, 37(6), 893-914. http:/ / doi.org/10.1080/01411926.2010.506945

Hornby, G. (2011). Parental Involvement in Childhood Education: Building Effective School-Family Partnerships. New York: Springer Science+Business Media. http:/ / doi.org/10.1007/978-1-4419-8379-4_1

Hudson, C. G. (2005). Socioeconomic status and mental illness: tests of the social causation and selection hypotheses. . The American Journal of Orthopsychiatry, 75(1), 3-18. http:/ / doi.org/https:/ / doi.org/10.1037/0002-9432.75.1.3

Isaacs, J. (2012). The Social Genome Project. School at a Disadvantage: The School Readiness of Poor Children. Centre on Children and Families at Brookings, (December 2011), 1-22.

Jenkins, J. V. M., Hooper, S., Woolley, D. P., \& Bellis, M. de. (2013). Direct and Indirect Effects of Brain Volume, Socioeconomic Status and Family Stress on Child IQ. Journal of Child and Adolescent Behaviour, 1(2). http:/ / doi.org/10.4172/2375-4494.1000107

Kohl, G. O., Lengua, L. J., \& McMahon, R. J. (2000). Parent involvement in school conceptualizing multiple dimensions and their relations with family and demographic risk factors. Journal of School Psychology, 38(6), 501-523. http:/ / doi.org/10.1016/S0022-4405(00)00050-9

Laurin, J. C., Geoffroy, M. C., Boivin, M., Japel, C., Raynault, M. F., Tremblay, R. E., \& Côté, S. M. (2015). Child care services, socioeconomic inequalities, and academic performance. Pediatrics, 136(6), 1112-1124. http://doi.org/10.1542/peds.20150419

Lazarus, R. S. (1993). From Psychological Stress to The Emotion: A History of Changing Outlooks. Annual Review of Psychology, 44, 1-21. http:/ / doi.org/https:// doi.org/10.1146/annurev.ps.44.020193.000245

Leinonen, J. A., Solantaus, T. S., \& Punamäki, R. L. (2002). The specific mediating paths between economic hardship and the quality of parenting. International Journal of Behavioral Development, 26(5), 423-435. http:/ / doi.org/10.1080/01650250143000364

Magnuson, K. A., \& Waldfogel, J. (2005). Early childhood care and education: Effects on ethnic and racial gaps in school readiness. Future of Children, 15(1), 169-196. http:/ / doi.org/10.1353/ foc.2005.0005 
Majzub, R. M., \& Rashid, A. A. (2012). School Readiness Among Preschool Children. Procedia - Social and Behavioral Sciences, 46(Schweinhart 2003), 3524-3529. http:/ / doi.org/10.1016/j.sbspro.2012.06.098

Masarik, A. S., \& Conger, R. D. (2017). Stress and child development: A review of the Family Stress Model. Current Opinion in Psychology, 13, 85-90. http:/ / doi.org/10.1016/j.copsyc.2016.05.008

Miech, R. A., \& Shanahan, M. J. (2000). Socioeconomic status and depression over the life course. Journal of Health and Social Behavior, 41(2), 162-176. http:/ / doi.org/10.2307/2676303

Nurhayati, W. (2018). Pengembangan Instrumen Kesiapan Bersekolah dan Pemetaan Kesiapan Bersekolah Pada Anak Usia Dini di Indonesia. Indonesian Journal of Educational Assessment, 1(1), 11-22.

Pan, Q., Trang, K. T., Love, H. R., \& Templin, J. (2019). School Readiness Profiles and Growth in Academic Achievement. Frontiers in Education, 4(November). http://doi.org/10.3389/feduc.2019.00127

Pekdogan, S., \& Akgul, E. (2016). Preschool Children's School Readiness. International Education Studies, 10(1), 144. http:/ / doi.org/10.5539/ies.v10n1p144

Rathod, dr. G. r., \& Ningshen, mr. A. (2012). " Measuring the Socioeconomic Status of Urban Below Poverty Line Families in Imphal City, Manipur : a Livelihoods Study ." International Journal of Marketing, Financial Services \& Management Research, 1(12), 62-69.

Santiago, C. D. C., Wadsworth, M. E., \& Stump, J. (2011). Socioeconomic status, neighborhood disadvantage, and poverty-related stress: Prospective effects on psychological syndromes among diverse low-income families. Journal of Economic Psychology, 32(2), 218-230. http:/ / doi.org/10.1016/j.joep.2009.10.008

Setiawati, F. A., Izzaty, R. E., \& Triyanto, A. (2017). Exploring the construct of school readiness based in child development for kindergarten children. REiD (Research and Evaluation in Education), 3(1), 42-49. http:// doi.org/10.23959/sfdorj-1000014

Shaari, M. F., \& Ahmad, S. S. (2016). Physical Learning Environment: Impact on Children School Readiness in Malaysian Preschools. Procedia - Social and Behavioral Sciences, 222, 9-18. http:/ / doi.org/10.1016/j.sbspro.2016.05.164

Sunarti, E. (2012). Keragaan Ketahanan Keluarga Indonesia: Pembangkitan Teori (Middle Range Theory) dan Rumusan Kebijakan Ketahanan Keluarga Indonesia. Laporan Pelaksanaan Kegiatan Hibah Kompetensi Tahun 2012. Bogor.

van Zyl, E. (2011). The relationship between school readiness and school performance in Grade 1 and Grade 4. South African Journal of Childhood Education, 
1(1), 82-94.

Waanders, C., Mendez, J. L., \& Downer, J. T. (2007). Parent characteristics, economic stress and neighborhood context as predictors of parent involvement in preschool children's education. Journal of School Psychology, 45(6), 619-636. http:/ / doi.org/10.1016/j.jsp.2007.07.003

Williams, D. T., Cheadle, J. E., \& Goosby, B. J. (2015). Hard Times and Heart Break: Linking Economic Hardship and Relationship Distress. Journal of Family Issues, 36(7), 924-950. http:/ / doi.org/10.1177/0192513X13501666

Williams, P. G., \& Lerner, M. A. (2013). School readiness. JAMA Pediatrics, 167(8), 784. http://doi.org/10.1001/jamapediatrics.2013.2959

Wilmoth, J. D. (2009). The ABC-X model of Family stress in the book of philippans. Journal of Psychology and Theology, 37(3), 155-162.

Xie, J., \& Gan, Y. (2017). Family environment impact on school readiness of children in China - based on the survey of Wuchuan Autonomous County, Guizhou. Eurasia Journal of Mathematics, Science and Technology Education, 13(10), 6609-6618. http:/ / doi.org/10.12973/ejmste/78175

Yüksel, M., Küçükoğlu, E. K., \& Ünsal, F. özge. (2013). Analysing the School Readiness of Preschoolers From the Aspect of the Social. International Journal on New Trends in Education and Their Implications, 4(April), 6249.

Zang, Y. (2012). Maternal Depression and Children's Development: Evidence from Children in Fragile Families. University of Miami.

Zeynep, K. (2016). Analyzing parental involvement dimensions in early childhood education. Educational Research and Reviews, 11(12), 1149-1153. http:/ / doi.org/10.5897/err2016.2757 